\title{
THE CONTEMPORARY CONSUMPTION AND THE HUMAN BODY
}

\author{
V.Stanev* \\ Department of Marketing and International Economic Relations, Faculty of Economic and Social \\ Sciences, Plovdiv University "Paisii Hilendarski”, Plovdiv, Bulgaria
}

\begin{abstract}
Two consecutive texts consider the question of the human body with its natural and interdependent entities - physical and social, as a reagent of the consumption, the development of this consumption over the years and its impact on the appearance and the growth of the new industries. The first paper focuses on the historical, socio-cultural and economic characteristics of the contemporary postmodern consumption.
\end{abstract}

Key words: postmodern consumption.

Modern times are broadly referred to as the age of Enlightenment which includes both the revolutionary governments and the western project for freedom, equality and fraternity - a society ruled not by royal whims and decrees but by reason and its laws. More specifically, it covers the Industrial age and the development of mechanized industry in the 19th and the 20th century. Yet, modernity is most often associated with the invasion of capitalism and the scientific materialism of the Western society postulating the mechanical universe governed by the laws of mechanics and physics (1). Several articles and studies published in past years have already outlined the political, economic, cultural, social, psychological and media specifics of Modern and Postmodern Age enunciating their determinative differences ${ }^{1}$. This article is the first part of two successive materials, it starts with a summary of the Postmodernism markers related with contemporary individual consumption.

\section{Postmodern man and his consumer dominants}

The deepest rift between modern and postmodern is felt in culture and consumption. The planet is seized by the culture of mass consumption, by a globally shrinking world, by postmodern individualism and rational instrumentalism that have marched their way through letting off the old moral horizons. As

${ }^{1}$ (See 2, 3, 4 and 5). early as in the 19th century, Alexis de Tocqueville wrote that people suffered from lack of passion. Kierkegaard made the same observations and Nietzsche's "last" people were the finished product of that decadence not striving to remain in the stream of life, men would rather seek little base amenities (6). They are the consumer people whose hedonistic and narcissistic self-expression is derived from incrementalism and consumption. People lose their breadth of horizon because their concentration is now fixed on individual existence, possession and consumption. In the name of consumption, unequal distribution of wealth is still an issue of great concern for mankind, but it remains indifferent to other pressing problems, environmental protection, for example, despite the glaring evidence of global warming. Nowadays, the culture of consumption is the major socializing factor of the modern ghost in the machine promising freedom, autonomy and immediate satisfaction of one's needs. It is an all-pervading germ that affects both the civil society and the very structure of the Self from early childhood like a virus which tells you "buy me, eat me, dream about me, crave for me and you will be yourself!" In fact, the big fallacy of infinite

\footnotetext{
*Correspondence to: Velin Stanev, Department of Marketing and International Economic Relations, Faculty of Economic and Social Sciences, Plovdiv University "Paisii Hilendarski”, Plovdiv 4000, Bulgaria, 24 Tsar Asen St., GSM: +359 8882939 13,E-mail:velstan@yahoo.com
} 
possession in the virtual reality of consumption culture is losing the possession over one's own Self! The never-ending parade of consumer fantasies turns into a way of life. The Self is restated over and over again like changing clothes - the mankind's inner life becomes fully obedient to the outside world of the masses (1).

In postmodern times (7):

- the market is a self-regulating power whose biggest fear is the uniformity of tendencies, tastes and beliefs because such uniformity may destroy the market;

- the regulation of consumer behaviour has been replaced by consumer seduction;

- inculcating ideology is replaced by advertising;

the postmodern form of production (Information Revolution, office, segmentation, decentralization) and its related society global - para-class and office workers, has replaced the modern form of production (the Industrial Revolution, factories, uniform mass production which lowers prices and increases income, centralization) and its related society capitalism, owning class of the bourgeoisie, workers (8); moreover:

If the symbol of modernity is the conveyor, and mass production is the foundation of modern society, postmodern society is a society of consumers. There is a transition from mass production of uniform items to flexible micro markets and market niches.

While the grounds of modern economics is the national market, postmodern times are the times of global markets covering the whole world. Thus, even production targeted to a limited number of consumers with a specific (often extravagant) taste may become mass, cheap and profitable.

The different levels of individual and collective access to the material goods and services of the global capitalistic system determine the social and economic profile of all countries from the First, Second, Third and Fourth World. Americans are Americans, Bulgarians are Bulgarians and Indians are Indians due to their different ability to possess and consume cars, computers, education, lodging, dental care, etc. These lifestyle standards are only tactical hallucinations which urge the majority to live the standard. Corporations have created daily life models with interchanging simulations. The simulated differences are driven by copying models which have no prototypes and the missing identity (because it is all about production and consumption) is a parody of national diversity and global society. "The territorial segmentation of nations into nation-states simply ordains imagery historical units for dividing economical welfare depending on the proximity or remoteness to the central posthistoric streams of global capital, energy, goods and power" $(9,145)$.

Mass culture has been transformed into hedonistic, narcissistic culture of consumption, and consumption itself has drastically changed its nature. While in modern society consumption is primarily instrumental and targeted to meet the vital needs of men, i.e. consumption is consumption of the daily bread, of real products and services necessary for survival and a bare existence, postmodern consumption is a consumption of symbols. Brands are sensitive images. They are personified. Consumption is the new form of communication and measuring up with the other members of society. A man is what he consumes, wears, buys and consumes! Individual self-expression and self-assessment is made by means of consumption, the measure and assessment of the others is made in the same way. Consumption is a demonstration of affiliation to a certain social, economic, educational status. In fact, the consumer has already ceased to exist in a singular form. Unlike the modern project where the differences between consumers are determined mainly by their income, nowadays consumers are intricately segmented according to various markers where differences in tastes is not always proportional to the differences in income and education for example. There are now a manifold of carefully refined criteria for consumer differentiation (10).

The concept for a uniform standard of consumer behaviour has also been discredited. There are different consumer standards applicable to the different consumer groups. The standard uniform system of social values which has had a strong influence on the consumer choice for decades is now increasingly becoming less uniform, indistinct and non-specific. A norm for one person can be an anti-norm for other people, what seems attractive or beautiful to one person may appear ugly and inadequate to another.

Discredited and modified are also the milestone values in modern consumption philosophy. Mankind has lived a life of restrictions for centuries. Thrift (saving) and Rationality (reasonable spending) have been considered as supreme virtues and merits ${ }^{2}$.

${ }^{2}$ Certainly, this philosophy is adequate in case of low production, but it is a balk when the production can 
Nowadays, the paramount goal is to fight limited demand and constantly find ways to increase sales (11).

The philosophy of life in the postmodern times professes to give up any and all restrictions of our consumer desires. People buy on credit, go on a holiday on credit, live on credit, but still, they possess and consume. This is the new morality ventilated by thousands of advertising slogans insisting that you get rid of all cultural and reasonable trammels in the name of boundless consumption - do it, release yourself and enjoy life, buy it at all costs, just live...

Shopping is the new hormone of happiness and its slogan is "I consume, therefore I live!"

There is more to it than that. In the realities of global times, every science, industry and trade gives rise to its own neo-world generated by the intensive expansion of global exchange. Contemporary neo-worlds lack topos, ethical and national location - they are techno-regions of socially and economically modified cultural space. They are the new expressions of motherland and nation-state. They are simulations of territory, behaviour model, operational nets. Postmodern neo-worlds are the common ground of global transnational society in which those who hold the energy sources, control the production of computer software, manage the global media networks and the world communication systems are3. more important for the population than the leaders of the countries where such population is a resident.

\section{The human body as a natural and social unity}

All of the above is directly related to the human body of which the individual is both a master and a servant. Man is a natural, but also a social creature, consisting of two integrated and interrelated domains:

- body - created by nature and existing by the laws of nature

- personality - formed as a result of the interactions (socialization) with the social environment in which people live.

On one hand, the body has a powerful impact on the process of personality formation and plays a major role in our social perception of life. On the other hand, the individual is the landlord of the body and it is exploited in view of the individual's social needs and their satisfaction. People interknit their body in the context of social interactions and employ it as

increase as a result of the scientific and technical revolution. a tool of reaching social goals! Nowadays, the body is an asset that brings in revenue. People invest in their bodies to get high return! But body's functions and the purpose of investment change with every stage of the capitalistic society. For the industrial modern society, the body is primarily work force, unlike postmodern global society today where it is a narcissistic cult object and an element of social rituals and tactics with two keynotes - beauty and erotics (12).

To sum up, the body dictates its needs to the individual, the individual is compelled to take notice of those needs and fight for meeting them by means of the resources available in the respective society. However, the body is also used for attaining certain social and economic goals. Most bodily urges are met by consuming material goods and services, i.e. the role of the body is ambivalent - it is simultaneously a source of needs and a means of satisfaction. This is why body maintenance requires:

- meeting its natural needs;

- using it to attain certain social and economic goals

The two bodies of a man - the physical (constructed by nature and more or less specific according to the social type) and the social (constructed by society) are constituents of one and the same body. Let us focus on the physical one.

\section{Natural needs of the body and consumption ${ }^{3}$}

The natural (physiological) needs of the human body are those objective necessities which make its normal functioning and existence possible. The signs of nature when the need of air, water, nutrition, protection from unfavorable weather conditions, rest, sleep, reproduction, movement, excretion has not been met are conveyed through signals of discomfort, physical pain, diseases, death. It is a fact, however, that intentional human actions of meeting the above needs in the required proportions are motivated by the notion, rather than the need itself. The body 'sends' a signal of dissatisfaction but man deciphers that signal individually. Thus, if thirsty, some people will drink any water (taking no consideration if that water is contaminated or infected) others will seek evidence if the water is drinkable before they taste it, or sterilize it, or even buy beer instead! In other words, our mind is a conscious sieve which turns natural needs into an urge for consumer behaviour, therefore, they can be analyzed only within the

${ }^{3}($ See $7,9,10,11,12,13,14)$. 
framework of the culture, norms, values and worldview of the social environment to which the individual belongs, as well as the degree of integration to such environment. The body sends impulses to indicate urgent needs which people decode according to the rules dominating in the culture of the country and inherent to the epoch.

This results in the outgrowth of perceived needs that stretch into particular interests which, in turn, mature into powerful stimulus for consumer behaviour.

perceived needs emerge as a result of socialization. People usually meet such needs in the way they have learned it in their early childhood. This is why nutrition (for example) is a traditional social act which takes places almost automatically, without doubt and much consideration, but in the customary way of the society. There are possibly (or rather normally) variant means of meeting one and the same needs in different societies. In the culture of nutrition of the postmodern times, however, there is an apparent trend of diffuse distribution - the norms in a given country (neighboring countries) pervade into other countries. The initiators or the 'cultural agents of pervasion' are usually travelers, traders and conquerors. Their function has been successfully taken over by tourism, television, cinema, commercials, Internet. International trade provides access to uncustomary products, advertising pumps up the necessary seduction/desire. Immigrants from Italy, China, India flush America and Western Europe open restaurants and trade with the ingredients of their national cuisines. When local people accept exotic and initially outlandish food, it becomes customary and typical, although actually it is not. Typical example is the Italian pizza which millions of people have long forgotten to be a traditional Italian food. The same applies to spaghetti which have been legitimated as local food worldwide as giant local organizations and chains of no Italian origin whatsoever produce pasta in bulks. Once an exotic rarity, coffee is nowadays a mate, a fellow, a habit, a ritual and an integral part of the daily life of the entire mankind. It is hardly likely that today's young Europeans realize that potatoes, tomatoes, rice and tobacco are not traditional European vegetable crops. The very instance of national cultural autonomy of food and nutrition is rather absurd in postmodern global times. Transnational McDonald's burgers are practically everywhere. The simulation of cuisine in fast food restaurants brings up its own models of culture, behaviour, desires confined within the conditions of fast capitalism. Unlike the times when each country used to be a distinctive cultural reality which people can get to know only by on site visit, globalization articulates the hyperreality integrating fractions of one and the same cultural reality in every corner of the planet Chinese restaurants and pizzerias have long since crossed the borders of their motherlands, they have even started to take root and adapt to local cuisine.

Medical Enlightenment has refined people's perception for normal intake of food and drinks, and has helped them realize the link between the various types of nutrition, illnesses and life expectancy. Interests invariably change as a result of the structure of the perceived needs. The germination of the negative image of bacteria in the mass consciousness will radically change the attitude to drinking water. This is how, as early as the period between the two world wars, the economic, educational and political elite realized the need of clean, safe water. Meanwhile, developed industrial societies and the overall industrialization of the planet "produce" the industrial pollution. Green organizations, in turn, raise the public concern on the hazardous substances resulting exactly from the same pollution, thus creating a new type of attitude - a necessity not simply of water free of microbes and bacteria but also water free of hazardous chemical components which already evokes economic interests. Mineral, table, spring water emerge on the market, new facilities for water purification and even nutrient saturation are developed.

Health awareness has likewise radically changed the structure of our perceived needs for nutrition. This has created strong economic interest in the development of organic and ecofriendly products for consumers who are ready to pay much more for fruits and vegetables without synthetic additives. Expressions like "organic" "environmentally friendly" or "bio-" have a mantra effect on some consumer groups (sometimes referred to as "greenwashing"), the same applies for products with reduced fat, sugar and salt content. This tendency has also led to gradually declining demand or full abstaining from the consumption of meat, milk and butter products.

Once "abnormal" and deviating from the standard, vegetarianism has now become a style of behaviour close to mania in its extreme forms of complete abstinence from animal products. The wide spread of knowledge about the role of vitamins have also changed consumer needs, creating the respective economic interest and demand, consequently 
saturating the market with vitamin enriched products.

Normal functioning of human beings requires breathing - a necessity proven remarkably early by evidence of death sentences executed through all types of suffocation in the ancient times. On a much later stage people realize that air must be saturated with oxygen and the collocations "clean air", "humid air", "dry air" started to appear as a defense strategy to disease tolerance. The need of clean or fresh air has hit the market since the mid 20th century - big city residents started to feel the need of going out from the city to "get some fresh air", leading to the need of owning a villa, building resorts and holiday homes, setting prices determined by the air quality of the recreation area.

During the second half of the 20th century, the dominating need of healthy lifestyle started to take firm hold not only through the emergence, modification and adoption of the respective social stereotypes, but also through a huge market including gym and health club attendance, home fitness training programmes using special sport equipment and accessories. The vigorous commercial stream cultivate this interest even further.

Pain is one of the indications that something in our body might be wrong and with the increasingly ability to predict the needs of the ailing body, people, quite naturally, fight it with various means. With the development of medicine, the number of available drugs has significantly increased. As long as pain is a signal of a need which cannot be ignored, the medical market thrives. Nobody would save on healthcare, besides, the social development itself increases the number of health-conscious people. Medical Enlightenment has sharply heightened people's awareness of diseases and treatment - today we spend billions to treat illnesses that nobody has even heard of 100 years ago!

In addition, preventive treatments have steadily gained pace as vaccine and immunization practices, as well as all kinds of "insurance in advance ${ }^{4}$.

After all, man eats, drinks and seeks health care because of the demanding sensations of hunger, thirst and pain. In reality, however, the laws regulating social norms, culture and values are difficult to escape because the

\footnotetext{
${ }^{4}$ Including the doubts that the majority of diseases are "released" from the same laboratories providing the respective treatment to secure successful marketing, as well as the suspicions of advertising urgent treatments to already familiar diseases or medications for non-existing illnesses.
}

ability to fix our eyes on our bodies and exert close scrutiny in order to protect and take care of them depends both on objective and subjective factors - it is a set of symbols which can be written, read, transmitted and perceived by the others. The human body as a civilizationally determined text can be read by the surrounding participants in the process of social decrypting. The ideal Renaissance woman has generous proportions with large hips and bosom - symbolizing power, beauty and fertility. Today, women with such body curves are called "fat" just like modern women would no doubt look like walking death in the eyes of the Renaissance man. Fat men used to be perceived as robust and mighty, a far cry from being overweight nowadays, when obesity is a risk factor for a number of diseases. The fat body is a script of meaningful signs suggesting information about metabolic disorders, high blood sugar level, medication therapy, weak-will, laziness, low physical activity and binge eating. Slimness is yet another script with various interpretations which are further complicated by individual highlights such as pallor, colour, posture, muscles, etc.

\section{REFERENCES}

1. Халтън, Ю. 2004. Модерната грешка, или непосилното просвещение на битието. - В: М. Федърстоун, С. Лаш, Р. Робертсьн (съставители). Глобални модерности. С.: Критика и хуманизъм, 357-381.

2. Станев, В., 2012. От „прекрасния нов свят" на модернизма, през постмодерните „безпокойства”, до глокалните неосветове - в търсене на щастието от притежанието и консумацията. Сборник: Научни трудове - ФИСН, Том 8, П.: УИ „П.Хилендарски” (423-444).

3. Станев, В., 2012. „Модернизъм, постмодернизъм и потребителските им доминанти. $\mathrm{B}$ : Сборник „Изследователски методи и технологии в икономическите и социалните науки". П.: УИ „П. Хилендарски” (218-226).

4. Станев, В., 2012. Позитивизъм Vs интерпретатативизъм в проучванията на потребителското поведение В: Сборник „Изследователски методи и технологии в икономическите и социалните науки". П.: УИ „П. Хилендарски” (227-235).

5. Станев, В., 2013. Властта на рекламата и рекламата като власт B: Сборник „Традиции, посоки, предизвикателства” Том III. С.: УИ „П. Хилендарски Смолян" (26-34). 
6. Ницше, Ф. 1990. Тъй рече Заратустра. С.: Христо Ботев.

7. Бауман, 3. 1994. Спор о постмодернизме. В: Социологический журнал №4. 69-80.

8. Кинг, А. 2004. Времената и пространствата на модерността (или кому е нужен постмодернизмът?) - $\mathrm{B}$ : М. Федърстоун, С. Лаш, Р. Робертсън (съставители). Глобални модерности. С.: Критика и хуманизъм, 156-176.

9. Люк, Т. 2004. Новият световен ред или неосветените редове: власт, политика и идеология в информационните глокалности. - В: М. Федърстоун, С. Лаш, Р. Робертсьн (сьставители).
Глобални модерности. С.: Критика и хуманизъм, 134-155.

10.Ильин, И. 2000. Поведение потребителей. С.П.: Питер.

11.Бауман, 3. 2004. В търсене на удържащ център. - В: М. Федърстоун, С. Лаш, Р. Робертсьн (съставители). Глобални модерности. С.: Критика и хуманизъм, 199-217.

12.Baudrillard, J. 1998. The Consumer Society: Myths and Structures. L.: Sage.

13.Ильин, И. 1996. Постструктурализм, деконструктивизм, постмодернизм. М.: Интрада. 